Refl-buk; K. : Vakler, 2001. 256 [in Ukrainian].

Semenyuk O. A., Parashchuk V. YU. (2010). Osnovy teoriyi movnoyi komunikatsiyi: navch. posibnyk [Fundamentals of the theory of speech communication]. K.: VTS «Akademiya», 2010. 240 [in Ukrainian].

Chorniy V. YA. (2011). Formuvannya hotovnosti do profesiynoho spilkuvannya maybutnikh fakhivtsiv finansovo-ekonomichnoyi sfery: dys. ... kand. ped. nauk: 13.00.04 [Formation of readiness for professional communication of future specialists of financial and economic sphere]. Ternopil, 2011. 324 [in Ukrainian].

УДК 37.377

DOI: https://doi.org/10.35387/od.2(20).2021.117-125

\begin{abstract}
Нечепорук Яна Сергіївна кандидат педагогічних наук, докторант кафредри педагогіки та менеджменту освіти Центральноукраїнського державного педагогічного університету імені Володимира Винниченка
\end{abstract}

\begin{abstract}
Necheporuk Yana - Candidate of Pedagogical Sciences, Doctoral Student of the Pedagogy and Education Management Department of the Volodymyr Vynnychenko Central Ukrainian State Pedagogical University in Kropyvnytskyi
\end{abstract}

ORCID iD: https://orcid.org/0000-0003-1152-8030

E-mail: yananecheporuk83@gmail.com

\title{
ІННОВАЦІЙНІ ТЕНДЕНЦІЇ ТЕСТУВАННЯ У СФЕРІ ІНШОМОВНОї ПІДГОТОВКИ АВІАЦІЙНИХ ФАХІВЦІВ
}

Анотація. Стаття присвячена аналізу інноваційних тенденцій тестування майбутніх $і$ діючих авіаційних фрахівців. Досліджено процес впровадження Вимог щодо володіння професійною мовою (LPR) та зазначено, що значну кількість тестів на знання авіаційної мови було розроблено та впроваджено кожним суб’єктом надання освітніх послуг окремо. Підкреслено, що незважаючи на те, що їх розроблення, можливо, здійснено у відповідь на LPR ICAO відповідно до керівних матеріалів, викладених у Документі ICAO 9835, вони мають відмінності у тлумаченні основного матеріалу, методах тестування та, власне, у тому, що є ефективним тестовим інструментом LPR. Це зумовило відмінності у стандартах і практиках їх апробації. У статті висвітлено низку проблем, які можуть свідчити про недостатність ефрективності іншомовної підготовки LPR ICAO, що може поставити під загрозу безпеку авіації.

У статті обгрунтовано актуальність і доцільність підвищення рівня профресійної іншомовної підготовки спеціалістів з цивільної авіації, а також критерії оцінки мовної компетентності. Висвітлено особливості авіаційної англійської мови для ведення радіопереговорів та їх вплив на безпеку польотів. Зауважено, що авіаційне профресійне спілкування набуває все більшого значення, а методи його підготовки та перевірки постають як 
актуальні для наукових досліджень. Зазначено, що LPR ICAO безпосередньо стосуються зв'язку між пілотами та диспетчерами повітряного руху, а оцінка кваліфікації у сорері радіотелефонного зв'язку відіграє в LPR ICAO провідну роль. Обгрунтовано ряд ключових критеріїв як головних елементів загальної системи тестування, що мають безпосередній вплив на ефрективність тесту з авіаційної англійської мови. Підкреслено, що ці критерії дозволяють визначити, наскільки добре тестування відповідає цілям LPR та наскільки загалом результативність тестування $\epsilon$ достовірною та справедливою.

Ключові слова: тестування ICAO; іншомовна підготовка; LPR ІСАО; пілот; диспетчер УПР.

Necheporuk Yana

\title{
INNOVATIVE TESTING TRENDS IN THE FIELD OF FOREIGN LANGUAGE TRAINING OF AVIATION PROFESSIONALS
}

\begin{abstract}
The article is devoted to the development and innovative trends of testing future and current aviation professionals. The process of implementing the Professional Language Proficiency Requirements (LPR) was examined and it was noted that many aviation language proficiency tests were developed and implemented by each entity providing educational services separately. Although they may have been developed in response to ICAO LPRs and followed the guidance material set out in ICAO Document 9835, there were differences in the interpretation of the main material, testing methods and, in fact, what is an effective LPR test tool. As a result, there were differences in testing standards and practices. The article highlights a number of issues that may call into question the long-term effectiveness of ICAO LPR foreign language training and aviation safety threat.

The article notes that aviation professional communication is becoming increasingly important, and methods of its preparation and verification appear to be relevant for scientific research. It was analyzed that the ICAO LPRs relate directly to the communication between pilots and air traffic controllers. The assessment of radiotelephone skills is central to ICAO's LPR.

The article notifies that lack of consistency among LPR tests is a result of wide differences in test instrument design. Further, regulatory authorities do not yet have access to a common framework to evaluate LPR tests - a key initial step required to attempt to standardise LPR testing systems.

The article substantiated a number of key criteria as the main elements of the general testing system, which directly affect the effectiveness of the aviation English test. Each criterion plays a key role in how well the testing meets the objectives of the LPR and how overall the effectiveness of the testing is reliable and fair.
\end{abstract} controller.

Key words: ICAO testing; foreign language training; ICAO LPR; pilot; ATC

Постановка проблеми, її актуальність. 32003 року, коли вперше був опублікований Документ ICAO 9835 «Керівництво щодо впровадження вимог ICAO до володіння мовою», органи цивільної авіації та розробники 
тестів покладалися виключно на цей посібник для отримання інформації про те, як розробити й обрати найефективнішу систему тестування та оцінювання рівня іншомовної підготовки, що відповідає вимогам ICAО щодо володіння англійською мовою (LPR ICAO) для майбутніх та діючих авіаційних фрахівців. Намір полягав у тому, аби розробники тестів базували свою роботу на засадах Документу ICAO 9835. Таким чином новостворені системи тестування та оцінювання іншомовної підготовки почали використовуватись для загального ліцензування авіаційних спеціалістів на базі загальноприйнятого стандарту. Важливою метою LPR ICAO $\epsilon$ досягнення еквівалентності між різними тестами та рівнями ICAO.

Ці керівні принципи були розроблені, щоб допомогти органам цивільної авіації та організаціям, які беруть участь у розробці тестувань у ссрері авіаційної іншомовної підготовки, розпізнати та зрозуміти ключові питання, пов'язані з розробкою випробувань та їх впливом на загальну практику тестування.

Критерії, визначені в цих керівних принципах, $€$ основними питаннями, які формують загальну ефективність та придатність системи випробувань для оцінки диспетчерів повітряного руху та ліцензування пілотів.

Аналіз актуальних досліджень і публікацій. Кінець XX - початок XXI ст. характеризується появою багатьох наукових праць, що досліджують окремі аспекти професійного іншомовного спілкування. Проблема іншомовної підготовки авіаційних спеціалістів та принципи визначення рівня їх знань стала предметом аналізу в дослідженнях, Г.В. Асташової, Т.О. Брик, С.А. Ісаєнко, В.С. Коломієць, Н.В. Логутіної, Ю.О. Ніколаєнко, І.П. Радомського. Також слід згадати таких вітчизняних і зарубіжних учених, які вивчали принципи та методику професійної іншомовної підготовки: Н.І. Гез, І.О. Зимня, Г.А. Китайгородська, М.К. Колкова, А.В. Конишева, О.О. Леонтьєв, Л.В. Лієр, Р.П. Мільруд, Є.І. Пассов. Аналіз зазначених праць, документів, відомостей ICAO та власний пошук дозволяють визначити основні тенденції інноваційних методів навчання та тестування 3 профресійної англійської мови у сфрері авіації.

Наразі Міжнародна організація цивільної авіації (ICAO) у своїх нормативних документах та під час регулярних Асамблей та Конференцій розглядає проблему володіння професійно-орієнтованою англійською мовою льотним персоналом. Регулярно розробляються нові навчальні посібники, що містять рекомендації та профільний дидактичний матеріал для курсів з підготовки авіаційних спеціалістів. Але все ще не вдається повністю уникнути проблеми стандартизованого підходу щодо процесу тестування на знання авіаційної англійської мови, який включав би в себе усі необхідні критерії іншомовної підготовки в авіаційній галузі.

Мета статті - виявити та проаналізувати провідні інноваційні тенденції та ключові критерії у процесі тестування ICAO зі знання авіаційної англійської мови. Визначити головні аспекти, що заважають та, навпаки, удосконалюють процес іншомовної підготовки майбутніх та діючих авіаційних фрахівців. 
Виклад основного матеріалу дослідження. В ідеалі кожна держава мала б розробити, обрати та запровадити власну систему тестування, що повністю відповідала б існуючим вимогам ICAO щодо володіння англійською мовою. Впроваджений стандарт має забезпечити впевненість у рівнозначності держав в процесі освоєння авіаційної мови. Іншими словами, Документ 9835 ICAO повинен становити загальну платформу для будь-якої системи тестування та бути засобом сприяння еквівалентності під час оцінювання та присвоєння рівня ICAO щодо володіння авіаційною англійською мовою. Мета полягала в тому, що загальний та універсальний стандарт може бути впроваджений у всьому світі, незалежно від того, який тестовий інструмент використовується і в яких державах.

Тестовий інструмент у мовному тестуванні - це інструмент, розроблений для вимірювання конкретної вибірки мовних знань, умінь та поведінки учасників тесту. Інструмент дозволяє оцінювачам робити висновки про здатність учасників тестування використовувати певні мовні навички. Випробувальний прилад побудований та зібраний таким чином, що всі форми випробування представлені однаково та мають однакову структуру. Він включає весь матеріал-зміст, вхідні дані, завдання або пункти та рубрику, з якими беруть участь і які доповнюють учасники тестування для цілей оцінювання. Випробувальний інструмент може виглядати як тестовий документ, набір запитань та змісту на екрані комп'ютера, питання екзаменатора, завдання, включені до буклету 3 інструкціями учасника тестування та екзаменатора.

У сфері тестування мови ця ініціатива ICAO є безпрецедентною. У галузі авіаційної іншомовної підготовки немає інших прикладів спроби розробити та впровадити загальномовний стандарт на міжнародному рівні, де різні види тестів розробляються та впроваджуються незалежно один від одного, при цьому базуються на загальній шкалі оцінок та чіткому переліку дескрипторів. Хоча Документ ICAO 9835 забезпечує загальні рамки для моделювання, розробки, відбору та адміністрування тестів, сам посібник слугує лише орієнтиром і не має на меті бути розпорядчим чи обов'язковим до виконання. Спеціалісти ICАО щодо вивчення авіаційної іноземної мови надали такі матеріали для того, аби заклади авіаційної освіти та міжнародна авіаційна промисловість могли розробити та впровадити випробування, які б лише покращували кваліфікаційні стандарти.

Документ ICAO 9835 був розроблений для полегшення розробки тестів, які найкращим чином відповідали можливостям та потребам розвитку місцевих випробувань, але все ще базувалися на загальному стандарті. Це ніколи не робилося в глобальному масштабі в жодній галузі. За перші десять років існування вимог щодо володіння мовою в авіаційній галузі проект досяг своєї мети. Держави успішно впровадили Вимоги ICAO щодо володіння мовою. Влада цивільної авіації, авіалінії та державні служби безпеки по всьому світу тепер усвідомлюють важливість володіння мовою для безпеки польотів та запровадили обов'язкові системи оцінки іншомовної підготовки персоналу. Володіння мовою зараз визнається як 
обов'язкова умова авіаційної діяльності. Мовна підготовка реалізується у глобальному масштабі у відповідь на ініціативи ICAO, а їх стандарти постійно покращуються.

Однак, незважаючи на існування вимог щодо володіння мовою в галузі авіації ще з 2008 року, сфрера авіаційної іншомовної підготовки має постійно удосконалюватись і покращувати існуючі стандарти. Це можливо втілити за рахунок посилення та вдосконалення стандартизації методів тестування. Такий процес має на своєму шляху низку перешкод, що безпосередньо впливають на гармонізацію глобальної системи оцінювання рівня іншомовної підготовки авіаційного персоналу.

Слід виокремити деякі з них:

- некоректне впровадження єдиного стандарту Вимог ICAO щодо володіння мовою на міжнародному рівні;

- відмінності в оцінці мовних знань та навичок, які оцінюються протягом тестування, і наскільки вони стосуються мови, комунікативних контекстів та рівнів володіння, необхідних для безпечних аеронавігаційних зв'язків;

- відсутність еквівалентності рівнів володіння мовою за стандартами ICAO, що були надані після проходження тестування;

- ринкові відносини, що сприяють появі та поширенню неякісних тестів, та брак коштів і ресурсів на їх перевірку;

- відсутність впевненості або навіть недовіра до рівнів ICAO, присуджених різними видами тестувань та державами;

- велика кількість тестів, заснованих на помилкових, непослідовних чи непридатних навчальних матеріалах, які негативно впливають на програми навчання мови та на якісному її засвоєнні, а також ставлять під загрозу безпеку цивільної авіації в цілому. Слід зазначити, що наразі існують навіть

На жаль подібна недоопрацьована система тестування авіаційного персоналу, щодо володіння мовою в результаті відображає велику кількість недоліків у тестових інструментах. Крім того, регулюючі органи ICAO поки що не мають повного доступу до існуючих засобів тестування, хоча зазначена умова постає найбільшим пріорітетним завданням у спробі стандартизації систем тестування LPR.

Модель тестового інструменту має велике значення для забезпечення якості та ефективності загальної системи тестування. Аби забезпечити еквівалентність та стандартизацію між тестуваннями LPR ICAO на міжнародному рівні, тестовий інструмент повинен включати ряд ключових елементів. Виявлення та виділення цих ключових елементів на основі Документу ICAO 9835 та найкращої практики оцінювання знання мов забезпечує чіткі параметри, щоб тести могли мати більше спільного з точки зору мовних навичок та знань мови, які вони оцінюють, та їх узгодження 3 потребами оцінки авіаційної іншомовної підготовки. Іншими словами, ці головні принципи мають на меті визначити базові елементи в процесі проектування тестового інструменту, які необхідно додати, аби дозволити проводити ефективне порівняння між тестуваннями. Це може полегшити 
встановлення міжнародних та міжтестових стандартів (International Civil Aviation Organization, Annex 1, Personnel Licensing).

Лише після того, як тестовий інструмент щодо оцінки іншомовної підготовки ICAO LPR буде доопрацьований, можна буде розробити та впровадити надійну та дієву систему стандартизованого тестування. Часто неправильно вважається, що досвідченість і професіоналізм оцінювачів визначає якість та ефективність системи тестування. Насправді оцінка може бути ефективною, лише тоді, коли тестовий інструмент розроблений детально та якісно. Замість оцінювача чи співрозмовника, саме тестовий інструмент визначає тип, діапазон та рівень складності мови, а також необхідну кількість застосованих навичок та контекстів для спілкування.

Отже, ці інновації в системі тестування авіаційної англійської мови спрямовані на те, аби надати роз'яснення та пояснення ключових питань, пов'язаних із розробкою тестових інструментів, щоб обмежити потенційну плутанину під час тлумачення Документу ICAO 9835. Майбутній Посібник чи Керівництво міститиме ґрунтовні пояснення того, чому ключові критерії мають вирішальне значення для ефективного тестування 3 авіаційної англійської мови. Настанови можуть розширювати, виходити за рамки або звужувати сфреру дії керівних принципів, викладених у документі ICAO 9835. Вони мають на меті зменшити можливості для різного тлумачення Документу 9835 щодо впровадження вимог ICAO до володіння мовою, що безпосередньо впливає на будову тестування ICAO та призводить до відмінностей між системами тестування. Подібні критерії були розроблені у відповідь на проблеми, що виникли у період з 2003 року, що спричинили таку розбіжність у практиці тестування LPR (International Civil Aviation Organization, Manual on the Implementation of ICAO Language Proficiency Requirements (Doc 9835).

Критерій 1. Тестові інструменти повинні містити відповідні завдання, які безпосередньо оцінюють те, як учасники тестування використовують мову у контексті радіотелефонної комунікації.

Автентичність матеріалу для тестування $€$ ключовою вимогою в процесі оцінювання рівня професійної іншомовної підготовки авіаційного персоналу. Це означає, що тестові завдання (інструменти) повинні містити завдання, де оцінюється здатність учасників тесту спілкуватися в ситуаціях авіаційної радіотелефонії за всіма шістьома критеріями рейтингової шкали ICAO. Чим більше наповненість тесту та його контекст пов'язані 3 реальними комунікативними ситуаціями, в яких працюють пілоти та диспетчери управління повітряного руху (УПР), тим більш достовірним і дійсним $€$ тест. Аутентичність максимізується шляхом забезпечення тестових інструментів завданнями, що відображають ситуації радіотелефонної комунікації, і змушують учасників тесту продемонструвати свої мовні здібності як у мовленнєвому, так і в аудіювальному компонентах тесту (ICAEA, «ICAO LPR Test Design Guidelines \& Workshops»).

Критерій 2. Розробка окремих тестових інструментів для пілотів та диспетчерів повітряного руху.

Структура тестових інструментів для пілотів та диспетчерів 
повітряного руху може виглядати схожою, однак зміст та вимоги до завдань мають відрізнятися та відображати мовні потреби та комунікативні контексти, пов'язані з кожною професією.

Хоча під час радіообміну пілоти та диспетчери УПР і взаємодіють між собою, вони все ж таки виконують різні завдання, мають різні комунікативні цілі та піддаються різним обмеженням та когнітивним навантаженням. Вони спостерігають за ситуацією із зовсім різних позицій, не поділяючи однакових точок зору та психічних процесів. Наприклад, під час радіообміну пілотам переважно потрібно слухати вказівки диспетчера УПР, відповідати на запити, описувати проблеми та взаємодіяти з різними підрозділами УПР на всіх етапах польоту. 3 іншого боку, диспетчери УПР повинні слухати та спілкуватися з кількома бортами на одній і тій же частоті, в момент коли трафік проходить через зону їх відповідальності. Спеціалістам з УПР в основному потрібно стежити за рухом літаків, видавати інструкції, розуміти проблеми пілотів у нестандартних ситуаціях, надавати інформацію, поради та можливі рішення (International Civil Aviation Organization (2003), Annex 1, Personnel Licensing).

Ці різні професійні функції формують різні вимоги до мовних знань та навичок, що потрібні кожній із зазначених професії для спілкування. Простіше кажучи, мова, яку використовують та продукують пілоти має бути зрозуміла диспетчерам УПР та навпаки. Тому для пілотів та диспетчерів повітряного руху повинні бути розроблені окремі тестові інструменти, які відображатимуть їх окремі мови, контекст та потреби спілкування.

Критерій 3. Тестові інструменти повинні містити завдання, що визначають рівень аудіювання, окремо від завдань, що призначені для оцінки мовленнєвої діяльності.

Тести мають містити розділи і частини, призначені лише для оцінки розуміння аудіювання. Це означає, що учасники тесту мають прослухати записані записи, а потім виконати подальші завдання 3 розуміння. Такі завдання можуть бути викладені на папері, вимагати від учасників тестування узагальнення інформації або відповіді на прописані письмові запитання, поставлені усно або подані на тестовому папері/екрані комп'ютера.

За допомогою тестів також можна оцінити (суб'єктивно) розуміння в інтерактивному контексті (окрім того, що він має виділений розділ тестування на слухання, але не виключає включення спеціальних розділів тесту на розуміння аудіювання). У таких ситуаціях суб'єктивні оцінки слід використовувати для підтримки результатів окремих розділів прослуховування.

Критерій 4. Тестові інструменти мають складатись з окремих розділів і з низки відповідних видів тестових завдань.

В процесі розробки тестів на визначення рівня ICAO з іншомовної підготовки присутні п'ять ключових питань, які необхідно вирішити на початку розробки будь - якого тестового інструменту:

- мовні навички та знання мови, що необхідно перевірити. Це лягає в основу конструкції тесту і впливає на всі питання, пов'язані 3 
конструюванням тестового інструменту;

- контекст реальних професійних ситуацій, що вимагає певні знання та навички;

- змістова наповненість тесту, що моделює реальне професійне спілкування;

- взаємозв'язок між змістовим наповненням тесту та знаннями мови, і як їх найкраще поєднувати під час складання тесту ICAO на володіння професійною авіаційною мовою;

- типи тестових завдань, які найкращим чином забезпечують i допомагають проявити свої знання під час складання іспиту.

Типи тестових завдань та елементи, які використовуються для побудови тесту, потрібно поєднувати таким чином, аби кожен 3 них відігравав певну роль у функціонуванні тестового інструменту. Вид, послідовність та поєднання тестових завдань повинні враховувати, наскільки ефективно кожне завдання може визначити певний набір мовних умінь та навичок (конструкція тесту). Поєднання тестових завдань має бути збалансованим, щоб належним чином відображати діапазон та різноманітність контекстів спілкування, в яких оцінюватимуть учасників тестування (Davies, 1990).

Висновки і перспективи подальших досліджень. Можливо, найбільш значущий внесок в дослідження проблем засвоєння мови і мовного тестування в останнє десятиліття внесла розробка теоретичних підходів до розуміння мовної компетентності, на основі яких можуть розроблятися системи тестування. Хоча існує кілька теорій щодо природи мови і процесу засвоєння мови і немає впевненості в правильності кожної 3 окремо взятих концепцій, $€$ кілька загальних принципів, якими можна керуватися при конструюванні мовних тестів. Останнім часом мовні дослідження були спрямовані переважно на вивчення комунікативних аспектів використання мови. Наразі ж проблему оволодіння професійною авіаційною мовою планується вивчати та досліджувати шляхом інтерактивного та комунікативного підходів. Інтерес до комунікативних підходів у сфері іншомовної підготовки привів також і до корінного перегляду практики мовного тестування ICAO, призначеного для прямої оцінки мовних умінь за допомогою нових тестових інструментів.

Перспективним напрямом подальших наукових пошуків уважаємо дослідження новітніх принципів, критеріїв тестування ICAO на знання авіаційної англійської мови, а також специфіки міжнародної стандартизації тестового інструменту ICAO та його змістового наповнення.

\section{Список використаних джерел}

International Civil Aviation Organization. (2004). Manual on the Implementation of

ICAO Language Proficiency Requirements (Doc 9835).

International Civil Aviation Organization. (2003). Annex 1. Personnel Licensing. Davies, A. (1990). Principles of Language Testing. Basic Blackwell.

Douglas, D. \& C. Chapelle. (2006). Assessing Language through Computer Technology» Cambridge University Press. 
Graddol, D. (2006). English Next The British Council Publications. London, UK.

ICAEA, (2021). ICAO LPR Test Design Guidelines \& Workshops. URL: https://www.icaea.aero/projects/icao-lpr-tdg/

ICAEA. (2019). TDG WORKSHOPS 2019: Using the ICAO LPR Test Design Guidelines». URL: https://www.icaea.aero/projects/icao-lpr-tdg/workshops/

УДК 37.015.3:[003.63:364-787.26]:[373:378]

DOI: https://doi.org/10.35387/od.2(20).2021.125-133

\begin{tabular}{|c|c|}
\hline $\begin{array}{lrr}\text { Рибалка } & \text { Валентин } \\
\text { Васильович } & - & \text { доктор } \\
\text { психологічних наук, } & \text { професор, } \\
\text { провідний науковий співробітник }\end{array}$ & $\begin{array}{lll}\text { Rybalka } & \text { Valentyn } & - \\
\text { of Sciences in } & \text { Psycholor } \\
\text { Professor, Leading } & \text { Researcher } \\
\text { of the Labour } & \text { Psychology }\end{array}$ \\
\hline $\begin{array}{l}\text { відділу психології праці } \\
\text { lнституту педагогічної освіти } \\
\text { i }\end{array}$ & $\begin{array}{l}\text { Department of the Ivan Ziaziun } \\
\text { Institute of Pedagogical and Adult } \\
\text { Education of the NAFS of Ukraine }\end{array}$ \\
\hline
\end{tabular}

Зязюна НАПН України

ORCID iD: https://orcid.org/0000-0002-8279-7468

E-mail: valentyn.rybalka@gmail.com

\title{
ПСИХОПЕДАГОГІКА ПРОЄКТНОЇ ДІЯЛЬНОСТІ ОСЕРЕДКУ ТЕРИТОРІАЛЬНОЇ ГРОМАДИ В УМОВАХ ДЕЦЕНТРАЛІЗАЦІЇ
}

\begin{abstract}
Анотація. У статті проаналізовано досвід організації проєктної діяльності освітянського осередку територіальної громади як форми ії демократичної поведінки в умовах рефоорми децентралізації влади. На основі узагальнення поглядів американського фрілософа і педагога Д. Д'юї, педагогічної системи А.С. Макаренка, досвіду відповідної роботи громадянського суспільства Швейцарії, США та офріційних документів, зокрема Конституції України (1996), Указу Президента України «Про сприяння розвитку громадянського суспільства в Україні» від 26 лютого 2016 року (2016), Концепції розвитку громадянської освіти в Україні (2018) тощо, запропоновано проєктно орієнтований алгоритм роботи освітянського осередку громадянського суспільства в умовах закладів освіти як центрів територіальних громад. Даний алгоритм був апробований в ході психологопедагогічних експедицій в ряді областей України у формі проведення тренінгу. Він передбачає 5 етапів, що відповідають принципам і процедурам демократії, засадам формування осередку громадянського суспільства, організації його продуктивної роботи, зокрема: 1. Збір членів громади, ї самоорганізація та правова підготовка. 2. Висування нагальних ініціатив, проблем, обговорення пропозицій та їх пріорітетивізація шляхом голосування. 3. Формування осередком проєктів вирішення пріоритетних проблем та їх прийняття референдумом. 4.Мобілізація суспільних, державних, кадрових, фрінансових ресурсів на виконання прийнятих проєктів. 5. Втілення проєктів у життя.

Вказаний алгоритм, тренінг і побудована на його основі технологія роботи реалізуються через послідовність дій освітянського осередку громадянського суспільства, що відповідають специсріці та графріку роботи
\end{abstract}

